\title{
STRATEGI PEMERINTAH DAERAH DALAM PENANGGULANGAN BENCANA BANJIR DI KABUPATEN BANTAENG
}

\author{
Nasyiruddin ${ }^{1}$, Muhammadiah2, Muhammad Yusuf Badjido² \\ 1Program Studi Ilmu Pemerintahan Fakultas Ilmu Sosial dan Ilmu Politik \\ Universitas Muhammadiyah Makassar \\ Jl Sultan Alauddin No 259 Makassar 90221 \\ nasyiruddin@gmail.com \\ 2Program Studi Ilmu Adiministrasi Negara Fakultas Ilmu Sosial dan Ilmu Politik \\ Universitas Muhammadiyah Makassar \\ Jl Sultan Alauddin No 259 Makassar 90221 \\ muhammadiah@unismuh.ac.id yusufbadjido@yahoo.com
}

\begin{abstract}
This study reviews the strategy Disaster Management Agency (BPBD) in response to floods in Bantaeng. The method used in this research is qualitative descriptive approach. Data collection techniques in this research is observation, interview, and documentation are carried out directly by the researchers. The results showed that: the construction of reservoirs carried out by the Local Government Bantaeng been implemented; greening performed as absorption of water from upstream areas (mountains) to reduce the amount of discharge flow of water to downstream areas; the construction of the walls of the coast as a breakwater in coastal areas has not done well; the provision of facilities and infrastructure to support the establishment of programs such as dam construction, reforestation and coastal building walls; raising community awareness of flood prevention is still not good.
\end{abstract}

Keywords: strategy, local government, disaster management.

\begin{abstract}
ABSTRAK
Penelitian ini mengkaji tentang strategi Dinas Penanggulangan Bencana Daerah (BPBD) dalam menanggulangi bencana banjir di Kabupaten Bantaeng. Metode yang digunakan dalam penelitian ini adalah pendekatan deskriptif kualitatif. Teknik pengumpulan data dalam penelitian ini adalah observasi, wawancara, dan dokumentasi yang dilakukan secara langsung oleh peneliti. Hasil penelitian menunjukkan bahwa: pembangunan waduk yang dilakukan oleh Pemerintah Daerah Kabupaten Bantaeng sudah terlaksana; penghijauan yang dilakukan sebagai resapan air dari daerah hulu (pegunungan) untuk mengurangi banyaknya aliran debit air ke daerah hilir; pembangunan dinding pesisir pantai sebagai pemecah ombak di daerah pesisir belum terlaksana dengan baik; penyediaan sarana dan prasarana untuk mendukung tercapainya program-program seperti pembangunan waduk, penghijauan dan membangun dinding pesisir pantai; peningkatan kesadaran masyarakat dalam
\end{abstract} penanggulangan banjir masih kurang baik.

Kata kunci: strategi, pemerintah daerah, penanggulangan bencana. 


\section{A. PENDAHULUAN}

Bencana banjir akan menimbulkan dampak yang merugikan di berbagai kehidupan masyarakat. Selain kerugian materi, kerugian moril yang timbul adalah kondisi mental yang menurun atau terganggu karena kehilangan harta benda akibat bencana banjir. Pada usia anak maupun orang dewasa, dampak bencana banjir dipandang sangat mengkhawatirkan, sehingga dalam Undang-undang Nomor 24 Tahun 2007 tentang Penanggulangan Bencana banjir dikategorikan sebagai kelompok rentan yang berbahaya.

Terjangan air bah terjadi akibat kondisi hutan yang gundul dan buruknya sistem drainase enam tahun silam. Delapan anak sungai di kaki Gunung Lompobatang (dimana tinggi gunung2.876 mdpl) mengalir ke kota tanpa terkendali. Saat puncak musim hujan datang, aliran air sungai yang datang dari berbagai sisi langsung mengepung kota. Kejadian ini yang membuat Pemerintah Kabupaten Bantaeng mempercepat kemampuan (BPDAS) menganalisa daerah rawan bencana banjir, maka DirJen (BPDAS) mengembangkan suatu sistem aplikasi yang di sebut sistem standar oprasional prosedur banjir. Berdasarkan Undang-undang sumber daya air, Nomor 7 Tahun 2004, Maka yang di maksud Daerah Aliran Sungai (DAS) adalah suatu daerah daratan yang merupakan suatu kesatuan sungai dan anak-anaknya, yang berfungsi untuk menampung, menyimpan dan mengalirkan air yang berasal dari curah hujan ke danau atau ke laut secara alami, yang batas ke barat merupakan pemisah topografi dan di batas kelaut sampai dengan peraliran yang masih berpengaruh aktivitas daratan.
Pentingnya suatu DAS dan cekdam digunakan sebagai unit perencanaan penanggulangan banjir yang utuh merupakan konsekuensi logis untuk menjaga kesinambungan pemanfaatan sumber hutan, tanah, dan air. Kurang tepatnya perencanaan dapat menimbulkan adanya degrasi Daerah Aliran Sungai DAS yang dapat menimbulkan banjir yang menimbulkan dampak negatif bagi masyarakat seperti yang di kemukakan di atas. Dalam upaya menciptakan pendekatan pengelolan DAS secara terpadu, diperlukan perencanaan secara terpadu, menyeluruh, berkelanjutan dan berwawasan dalam pengelolaan lingkungan dengan mempertimbangkan DAS sebagai unit pengelolaan. Bila bencana banjir tiba penanggulangannya dapat dilakukan secara menyuluruh yang meliputi DAS, mulai daerah hulu sampai hilir. Mengingat Kabupaten Bantaeng yang rawan bencana banjir pada tahuntahun sebelumnya, maka Pemerintah Kabupaten Bantaeng berusaha segera mengambil tindakan-tindakan yang tepat tentang penanggulangi bencana banjir tersebut, sesuai otonomi daerah untuk mengatur dan mengurus rumah tangganya sendiri, termasuk menanggulangi bencana banjir yang terjadi di daerah. kondisi dan potensipotensi serta kemampuan daerah itu sendiri yang disebut dalam Undangundang Nomor 32 Tahun 2004 yaitu, Daerah berhak, berwewenang dan berkewajiban mengatur, bertanggung jawab dan mengurus rumah tangganya sendiri termasuk dalam penanggulagan bencana banjir, sesuai dengan Peraturan Perundangundangan yang berlaku. Menurut Peraturan Perundang-Undangan Nomor 24 Tahun 2007 pasal 8 yang berlaku, Pemerintah Daerah dalam penyelenggaraan penanggulangan bencana daerah bertanggung jawab dalam hal: (1) Penjaminan pemenuhan hak masyarakat sesuai dengan standar 
minimum; (2) Melindungi masyarakat dari dampak bencana banjir; (3) Pengurangan resiko bencana dan pemanduan pengurangan resiko bencana dengan program pembangunan; dan (4) Pengalokasian dana penanggulangan bencana dalam anggaran pendapatan daerah yang memadai.

Maka dengan landasan ini, Pemerintah Kabupaten Bantaeng membentuk suatu PERDA Badan Penanggulangan Bencana Daerah (BPBD) Kabupaten Bantaeng Nomor 2 Tahun 2013 tentang Pembentukan Organisasi, Tugas dan Fungsi lembaga teknis Kabupaten Bantaeng.

\section{B. KONSEP STRATEGI}

Istilah strategi berasal dari bahasa Yunani strategia yang bermakna the art of the general atau seni seorang panglima yang biasanya digunakan dalam peperangan. Secara umum strategi adalah proses penentuan rencana para pemimpin puncak yang berfokus pada tujuan jangka panjang, disertai penyusunan suatu cara atau upaya yang di lakukan oleh sekelompok orang dengan maksud agar tujuan tertentu. Sedangkan secara khusus Strategi merupakan tindakan yang bersifat inkremental (senantiasa meningkat) dan terus-menerus, serta dilakukan berdasarkan sudut pandang tentang apa yang diharapkan oleh masyarakat di masa depan. Strategi hampir selalu dimulai dari apa sudah terjadi dan bukan dimulai dari apa yang belum terjadi. Selanjutnya salah satu aspek yang kerap kali dilupakan berkaitan dengan terjadinya banjir di satu kota adalah banjir itu sangat berkaitan erat dengan kesatuan wilayah yang disebut dengan Daerah Aliran Sungai (DAS). DAS sendiri didefinisikan sebagai satu hamparan wilayah dimana air hujan yang jatuh di wilayah itu akan menuju ke satu titik outlet yang sama, apakah itu sungai, danau, atau laut. Adapun strategi dalam pengelolaan DAS yaitu: (1) Pengelolaan dan konservasi lahan pertanian; (2) Pembuatan dan pemeliharaan saluran air; (3) Pembangunan terjunan air dan sebagainya; (4) Pemeliharaan tebing sungai; (5) Pengembangan infrastruktur yang sesuai, misalnya pembangunan sarana irigasi; dan (6) Tinggi tanggul sungai.

\section{Peran Pemerintah Daerah dalam Penanggulangan Banjir}

Peran berasal dari kata peran yang berarti sesuatu yang menjadi bagian atau memegang pimpinan yang terutama. Istilah peran digunakan dalam menunjukkan adanya tanggung jawab dari pemerintah daerah dalam penanggulangan bencana banjir. Adapun pemerintah itu sendiri berasal dari kata "perintah" yang berarti menyuruh melakukan sesuatu sehingga dapat dikatakan bahwa pemerintah adalah kekuasasan yang memerintah suatu Negara (daerah Negara) atau badan tertinggi yang memerintah suatu Negara. Adapun kebijakan pemerintah daerah terdiri dari beberapa tahap yakni:

\section{Penyediaan pelayanan;}

Untuk peran yang secara tradisional paling diasosiasikan dengan pemerintah regional, adalah penyediaan pelayanan-pelayanan yang berorientasi terhadap lingkungan dan kemasyarakatan termasuk penanggulangan bencana banjir. Pelayanan lingkungan yakni: jalan-jalan daerah, penerangan jalan, tempat pembuangan sampah, saluran air limbah, pencegahan terjadi banjir, taman-taman dan rekreasi, biasanya diselenggarakan oleh pemerintah daerah, meskipun kadang kala badan 
pembangunan perkotaan melaksanakan pembangunan awalnya. Hal ini di tuangkan UUD RI Nomor 24 Tahun 2007 Pasal 73 ayat pemulihan fungsi dan pelayanan publik sebagaimana dimaksud dalam Pasal 56 ayat 1 huruf j. Ditujukan memulikan kembali pelayanan masyarakat pada kondisi sebelum terjadi bencana. ayat (2) kegiatan pelayanan pada publik sebagaimana yang di maksud pada ayat 1 di lakukan melalui upaya, rehabilitasi dan pemulihan fungsi sarana dan prasarana pelayanan publik, mengaktibkan kembali fungsi pelayanan publik lembaga yang terkai, dan mengatur kembali fungsi pelayanan publik. Ayat (3) Pelaksanaan pelayanan publik sebagaimana yang dimaksud pada ayat 2 dilakukan dibawa kordinasi pimpinan pemerintah di daerah denagan dukungan BPBD dan BNPB.

\section{Pengaturan;}

Peran penyediaan jasa oleh pemerintahan regional disebut fungsi pengaturan terkait perumusan dan penegakkan (enforce) peraturanperaturan. Sementara pertahanan dan angkatan bersenjata selau menjadi tanggung jawab pemerintah pusat, penyelenggaraan ketertiban umum dan ketertiban kehidupan menurut hukum seringkali dilimpahkan kepada Pemerintah Negara bagian dalam suatu federasi, Kepala pemerintah regional (Gubernur provinsi, kolektor, distrik dan sebagainya), atau bahkan di Perancis, kepada walikota-walikota yang dipilih.

\section{Pembangunan;}

Peran pembangunan adalah pemerintah regional mungkin terlibat langsung dalam bentuk-bentuk kegiatan ekonomi, seperti mengoprasikan pabrik-pabrik, perkebunan, atau usaha perdagangan. Di Negara lain hal itu dapat diusahakan untuk mempribumikan kepentingan-kepentingan asing, untuk mendorong dan memberi contoh kepada sektor swasta, atau untuk menambah penerimaan. Permasalahan yang makin luas meminta perhatian adalah untuk meningkatkan dan mendukung perusahaan swasta melalui penyediaan prasarana lokasi lingkungan pembangunan waduk, perumahan pegawai, irigasi, pergudangan, jalan-jalan penghubung dan sebagainya atau melalui penyuluhan kepada masyarakat dalam bidang-bidang seperti pertanian, peternakan, perikanan, atau industri kecil.

\section{Perwakilan;}

Perwakilan dari Pemerintah Regional untuk menyatakan pendapat daerah atas hal-hal diluar tanggung jawab eksekutif umumnya dihubungkan dengan Pemerintah Negara bagian dan penerintah daerah. Fungsi ini penting dalam penentuan bobot dan pengaruh pemerintahan regional, tetapi peranan keuangannya langsung kecil.

\section{Koodinasi dan Perencanaan;}

Perencanaan dan pengkoordinasian sendiri bukanlah suatu fungsi yang besar pembiayaannya, tetapi peran tersebut mungkin meminta tanggung jawab bagi pelaksanaan programprogram pembangunan utama yang dibiayai secara internasional atau oleh pemerintah pusat. Sebagaimana dituangkan dalam UU RI Nomor 24 Tahun 2007 Pasal 58 menimbah bahwa: (1) Dalam melakukan rehabilitas Pemerintah Kabupaten/Kota wajib menggunakan 
anggaran pendanaan penanggulangan bencana dari APBD Kabupaten/Kota; (2) Dalam hal APBD Pemerintah Kabupaten/Kota tidak memadai, Pemerintah Kabupaten/Kota dapat meminta bantuan dana kepada provinsi atau pemerintah untuk melaksanakan rehabilitas.

Adapun pelaksanaan strategi penanggulangan bencana banjir yang di lakukan oleh Pemerintah Daerah di Kabupaten Bantaeng yaitu

a. Dalam upaya membangun penanggulangan bencana banjir Pemerintah Kabupaten Bantaeng membangun presepsi yang sama bagi semua pihak baik oleh jajaran pemerintah maupun jajaran masyarakat yang ketentuan langkahnya di atur oleh ketentuan pemerintah daerah (PERDA), Petujuk dan pelaksanaan yang di keluarkan oleh instansi yang bersangkutan sesuai dengan bidang dan tugas masing-masing;

b. Pelaksanaan penanggulangan bencana banjir dilaksanakan secara terpadu atau koordinir yang melibatkan seluruh potensi pemerintah dan lapisan masyarakat;

c. Upaya preventif harus di utamakan agar penanggulan tewujud agar kerusakan dan korban jiwa dapat ditanggulangi atau diperhitungkan dalam menanganinya;

d. Penggalangan kekuatan dengan melalui semua pihak, melalui pemberdayaan masyarakat serta kampanye penghijauan untuk melakukan penanggulangan bencana banjir;

e. Pemetaan langkah pertama dalam mengambil strategi irigasi adalah melakukan peninjauan daerah rawan bencana banjir. Agar selalu memberikan antisipasi untuk melakukan penaggulangan agar bencana banjir tidak terjadi;

f. Pemantauan dengan mengetahui tingkat kerawanan secara dini, maka dapat dilakukan penanggulangan tehadap bencana banjir, sehingga akan dengan mudah melakukan penanggulangan banjir. Pemantauan daerah vital yang strategis dan ekonomi di lakukan di beberapa kawasan rawan bencana banjir agar dapat mengambil tindakan dalam penanggulangan banjir;

g. Penyebaran imformasi dilakukan dengan cara memberikan poster dan leaflet kepada seluruh jajaran pemerintah Kabupaten Bantaeng yang rawan terkena bencana banjir, tentang cara mengenali, dan menangani penanggulangan bencana banjir. Memberikan informasi ke media cetak dan alat elktronik ke masyarakat tentang kebencanaan adalah salah satu cara mengabarkan informasi kepada pemerintah, agar pemerintah setempat yang berada di wilayah rawan bencana banjir bergerak untuk mengambil tindakan cepat dengan tujuan meningkatkan kewaspadaan terhadap kawasan rawan bencana banjir. Maka dalam hal ini di perlukan koordinasi akurat antara pemerintah, keaparatur camat kepada instansi desa yang rawan bencana banjir;

h. Sosialisasi dan penyuluhan tetang bencana banjir yang dilakukan oleh SATKORLAK BPBD dan, masyarakat yang bersangkutan bertujuan kedaerah kawasan banjir untuk meningkat kewaspadaan dan kesiapan dalam pengelolaan Daerah Aliran Sungai (DAS); 
i. Pelatihan/pendidikan difokuskan dengan tata cara pemeliharaan lingkungan alam dengan cara melakukan penghijauan sebagai peresap air agar terjadi bencana banjir. Pelatihan tersebut, lebih ditekankan pada alur informasi dan petugas lapangan, pejabat teknis, dan masyarakat supaya benar-benar paham dalam mengambil tindakan dalam penanggulangan banjir;

j. Peringatan dini dimaksudkan untuk memberi tahukan tingkat kegiatan hasil pengamatan secara berkelanjutan di daerah rawan banjir dengan tujuan agar persiapan penanggulangan bencana banjir secara dini dapat dilakukan agar dapat mencegah terjadinya terjadi bencana banjir. Peringatan dini tersebut di sosialisasikan oleh Pemerintah Kabupaten Bantaeng kepada instansi pemerintah setempat yang bersangkutan dengan tujuan memberikan kesadaran pada masyarakat dalam menghindarkan diri dari bencana. Selanjutnya pemerintah daerah ke masyarakat merupakan hasil pemantauan yang di lakukan di daerah rawan bencana seperti, berupa saran teknis dapat berupa antar lain pengalihan jalur aliran air, relokasi, dan saran penanganan lainnya.

\section{Faktor-Faktor Penyebab Banjir}

Adapun faktor penyebab terjadinya banjir Menurut Rizky Novi, (2013). antara lain: (1) Banjir karena sungai meluap merupakan banjir yang terjadi akibat dari sungai tidak mampu lagi menampung aliran air yang ada di sungai itu akibat debit airnya sudah melebihi kapasitas; (2) Banjir lokal adalah banjir yang terjadi akibat air yang berlebihan di suatu tempat dan meluap juga di tempat itu sendiri; (3) Banjir akibat pasang surut air laut adalah banjir yang terjadi saat air laut pasang, ketinggian muka air laut akan meningkat, otomatis aliran air di bagian muara sungai akan lebih lambat dibandingkan bila saat laut surut; (4) Peristiwa Alam merupakan jenis banjir diakibatkan oleh peristiwa mendadak seperti jebolnya bendungan atau bencana lain seperti gempa bumi dan letusan gunung berapi.

\section{METODE PENELITIAN}

Penelitian ini dilaksanakan di kantor Badan Penanggulangan Bencana Daerah (BPBD), tempat ini dipilih dengan pertimbangan geografis. Jenis penelitian yang digunakan adalah pendekatan deskriptif kualitatif, yaitu pengukuran yang cermat terhadap studi kasus fenomena sosial tertentu. Sumber data penelitian ini terutama disaring dari sumber data primer dan data sekunder dengan proporsi sesuai dengan tujuan penelitian ini.

Informan dalam penelitian ini digunakan untuk memperoleh data yang relevan sebagaimana yang diharapkan dalam tujuan penelitian, maka digunakan teknik pengumpulan data Observasi (pengamatan), dan dokumentasi. Analisis data dilakukan dengan menelaah data yang diperoleh dari istansi yang terkait, dalam penanggulangan bencana banjir di Kabupaten Bantaeng. Data yang diperoleh dari berbagai sumber atau informasi hasil penelitian penanggulangan banjir di daerah Bantaeng, baik yang diperoleh melalui data primer maupun data sekunder dilakukan secara deskriftif kualitatif dengan didukung hasil wawancara dan didukung beberapa variabel 
pendukung yang dijadikan indikator dalam penelitian ini. Setelah menganalisis data, peneliti harus memastikan apakah interpretasi dan temuan penelitian akurat. Triangulasi sumber dilakukan untuk menguji kredibilitas data dengan cara mengecek data yang telah diperoleh melalui beberapa sumber. Dalam hal ini, untuk menguji kredibilitas data tentang penerapan strategi penanggulangan bencana banjir di Kabupaten Bantaeng, maka pengumpulan dan pengujian data yang telah diperoleh dilakukan kepada, instansi terkait dan masyarakat di Kabupaten Bantaeng.

\section{HASIL DAN PEMBAHASAN}

\section{Strategi pemerintah daerah dalam pelaksanaan penaggulangan banjir di Kabupaten Bantaeng}

Adapun strategi yang di lakukan pemerintah dalam penanggulangan banjir antara lain menurut Ihsan Aswin Arahap dalam kompas harian Bantaeng :

1) Membangun waduk

Pentingnya suatu strategi yang matang dalam penaggulangan banjir sangat diperlukan, agar rasa khawatir dan takut yang menghantui masyarakat akan ancaman bencana banjir yang sewaktu-waktu dapat menerjang tidak terjadi. Membangun waduk adalah suatu strategi atau tindakan yang dilakukan oleh Pemerintah Kabupaten Bantaeng untuk menanggulangi dan mencegah terjadinya bencana banjir di Kabupaten Bantaeng.

$$
\text { Berikut hasill kutipan }
$$

wawancara dengan informan terkait yang berpropesi sebagai pemantau waduk tersebut mengatakan :

"Bahwa permasalahan besar yang tejadi di Kabupaten

Bantaeng tahun-tahun
sebelumnya kaerana tidak
terkendalinya pembangunan
tempat penampungan air
(waduk), sehingga jika
sewaktu-waktu terjadi hujan
deras maka air yang mengalir
dari daerah hulu kedaerah
hilir tidak bisa manampung
banyaknya debit air dan
Daerah Aliran Sungai
mengalir tak terkendali ke
daratan rendah
mengakibatkan terjadi
banjir". (Wawancara dengan
S)

Sehubungan dengan hasil wawancara dengan informan di atas, maka dapat dikatakan bahwa dengan adanya waduk/tempat penampungan air akan memudahkan untuk mengatur dan mengendalikan Daerah Aliran Sungai (DAS), sehingga tidak terjadi lagi bencana banjir, air yang biasanya mengalir kedaerah hilir yang menyebabkan banjir dapat dilarikan ke tempat penampungan. Sebagaimana diketahui bahwa salah satu faktor pemicu terjadi banjir karena tidak terkendalinya Daerah Aliran Sungai (DAS), dapat menimbulkan bencana banjr dan dampak yang buruk bagi manusia bahkan dapat merengut nyawa manusia. Berdasarkan Undang-undang Sumber Daya Air, Nomor 7 Tahun 2004, maka yang di maksud Daerah Aliran Sungai (DAS) adalah suatu daerah daratan yang merupakn suatu kesatuan sungai dan anak-anaknya, yang berfungsi untuk menampung, menyimpan dan mengalirkan air yang berasal dari curah hujan ke danau atau ke laut secara alami, yang batas kebarat merupakn pemisah topografi dan di batas kelaut sampai dengan 
peraliran yang masih berpengaruh aktivitas daratan.

Ada dua faktor perubahan kenapa banjir terjadi. Pertama, terkait perubahan lingkungan dimana di dalamnya ada perubahan iklim, perubahan geomorfologi, perubahan geologi dan perubahan tata ruang. Dan kedua adalah perubahan dari masyarakat itu sendiri. Hujan merupakan faktor utama penyebab banjir, perubahan iklim menyebabkan pola hujan berubah dimana saat ini hujan yang terjdi mempunyai waktu yang pendek tetapi intensitasnya tinggi. Akibat keadaan ini saluransaluran yang ada tidak mampu lagi menampung besarnya aliran permukaan dan tanah-tanah cepat mengalami penjenuhan. Pentingnya waduk untuk menopang kelangsungan perekonomian dan kehidupan masyarakat. Pengamatan tersebut didukung dengan pertanyaan yang disampaikan oleh tokoh masyarakat yang tinggal di Desa Allu area sekiar waduk/tempat penampungan air mengatakan:

"Bahwa sebelum adanya waduk/tempat penampungan air yang di bangun oleh Pemerintah Daerah Kabupaten Bantaeng tersebut, masyarakat yang tinggal banyak merasakan permasalahan terutama gagal panen karena pada saat musim hujan datang, itu disebabkan karena tidak teraturnya Daerah Aliran Sungai (DAS) Balang Sikuyu yang merupakan sungai terbesar dari Daerah Kabupaten Bantaeng sehingga dengan mudah mengalir daerah daratan yang rendah keareah persawahan warga dan merendam tanaman warga sehingga hasil panen jauh dari target sebelumnya yang biasa dia dapatkan. Namun setelah membangun waduk seluas 5 hektar dengan tinggi dinding 8 meter dan 20 meter yang berjarak 3 kilometer dari Kota Bantaeng, maka Daerah Aliran Sungai (DAS) dan anak-anaknya dapat dikendalikan dan masyarakat juga merasa aman dan tentram". (Wawancara DB)

Berdasarkan hasil wawancara tersebut mengindikasikan pentingnya pembangunan waduk sangat dibutuhkan oleh semua pihak baik pemerintah lebih-lebih di kalangan masyarakat untuk menopang ekonomi mereka. Tidak adanya waduk yang dibangun oleh pemerintah dalam menanggulangi bencana banjir, dapat berakibat fatal bagi masyarakat yang berada di daerah tersebut (Baca: Daerah Aliran Sungai). Peran pemerintah daerah yang menjadi penanggung jawab utama dalam mensejahterakan masyarakat dan melestarikan lingkungan, agar akselarasi pembangunan dan peningkatan kesejahteraan masyarakat bisa tercapai.

Untuk memahami berbagai pengaturan pendanaan bagi pemerintahan regional, seseorang harus mengerti keragaman fungsifungsi yang dibebankan kepada mereka. Dibutuhkannya peran pemerintah lokal yang secara terpadu dan terkordinir dalam hal penyediaan pelayanan, yang berorientasi terhadap lingkungan dan kemasyarakatan, agar masyarakat merasa aman dan tidak khawatir akan bencana banjir tesebut. Pengamatan tersebut didukung oleh pernyataan dari salah seorang masyarakat menyatakan : 
"Setelah adanya waduk/tempat penampungan air yang dibangun oleh Pemerintah Kabupaen Bantaeng maka permasalahan gagal panen diakibatkan oleh bencana banjir yang sering dialami tersebut sampai sekarang ini tidak terjadi lagi, banjir karena aliran sungai beserta anak-anaknya yang biasanya meluap sekarang dapat di atasi dengan adanya waduk yang bangun oleh pemerintah bekerjasama dengan Badan Penanggulangan Bencana Daerah (BPBD) dan lembaga kemasyarakatan".

(Wawancara DM).

Berdasakan hasil data yang di deskripsikan dari informan maka peneliti dapat mengambil suatu kesimpulan bahwa pentingnya pelayanan pemerintah daerah mengikutsertakan semua elemen yang terkait dengan penanggulangan bencana banjir, baik pemerintah daerah, Dinas Penanggulangan Bencana Daerah (BPBD) dan masyarakat itu sendiri.

2) Meyiapkan Sarana dan Prasarana

Adapun sarana dan prasarana yang digunakan oleh Pemerintah Kabupaten Bantaeng dalam penanggulanagan bencana banjir yaitu

a. Membentuk Badan

Penanggulangan Bencana Daerah (BPBD);

Berikut hasil Wawancara dengan informan Kepala Badan Penanggulangan Bencana Daerah (BPBD) Kabupaten Bantaeng mengatakan:

"dengan adanya suatu badan yang dibangun oleh pemerintah daerah yang mengerti dan ahli sesuai dengan bidangnya masingmasing dapat bertindak secara cepat, maka pelaksanaan penanggulangan banjir di Kabupaten Bantaeng ini, akan terlaksana dengan maksimal sesuai yang diharapkan". (Wawancara MM).

Berdasarkan dari hasil wawancara dengan Kepala Dinas menunjukan bahwa salah satu bentuk keseriusan Pemerintah Kabupaten Bantaeng dalam hal pelaksanaan penanggulangan banjir yaitu dengan adanya suatu badan khusus yang di bentuk oleh pemerintah guna untuk mengatasi masalah bencana banjir. Hal ini diselaraskan dengan Peraturan Daerah (PERDA) Pemerintah Kabupaten Bantaeng tentang pembentuk Badan Penanggulangan Bencana Daerah (BPBD) Kabupaten Bantaeng Nomor 2 Tahun 2013 tentang Pembentukan Organisasi, Tugas dan Fungsi lembaga teknis. Penguatan kelembagaan diwujudkan dengan melalui pembentukan visi dan misi, serta tugas pokok, lengkap dengan rincian tugas dan tanggung jawab lembaga dalam pengendalian pemanfaatan ruang di kawasan rawan bencana banjir, baik pada aspek pengawasan maupun penertiban. Mengingat dalam aspek penertiban harus melibatkan multi instansi yang ada, maka penguatan kelembagaan dilakukan dengan meningkatkan kemampuan lembaga melakukan koordinasi (sinergi) dengan lembaga lain, baik intern maupun ekstern. Kegiatan penertiban pemanfaatan ruang yang telah menyimpang dari rencana tata ruang, maka lembaga terkait yang berwenang harus melakukan operasi yang 
multikompleks secara terkoordinasi. Dalam aspek pengawasan, penguatan kelembagaan dilakukan melalui pemberian tugas dan tanggung jawab yang jelas, mulai dari monitoring, pemantauan, dan pembuatan laporan yang rutin, menerus, dan berkelanjutan.

b. Penyediaan alat penyedok tanah dan sampah.

Permasalahan besar yang terjadi di kalangan masyarakat perkotaan Kabupaten Bantaeng yang menyebabkan terjadinya banjir adalah kurang terpeliharanya lingkungan hidup seperti, saluran air kanal dan Daerah Aliran Sungai. Berikut adalah hasil wawancara dengan informan yang bersangkutan Keapala Dinas BPBD menyatakan :

"Faktor yang menyebabkan terjadi banjir di Kota Kabupaten pada tahun-tahun sebelumnya itu disebabkan karena banyak sampah yang tersumbat di tempat penyaluran air dan tidak adanya alat penyedok sampah yang di sediakan oleh pemerintah sehingga air meluap ke daerah daratan rendah ke daerah perkotaan. (Wawancara MM).

Terkait dengan hasil wawancara di atas, mengambarkan bahwa pentingnya penyediaan alat sarana dan prasaran berupa alat penyedok sampah sangat dibutuhkan untuk mencapai upaya preventif agar penanggulangan tewujud dengan cepat, sesuai dengan yang direncanakan serta ingin dicapai, agar kerusakan dan korban jiwa dapat di tanggulangi atau diperhitungkan dalam menanganinya. Pengamatan di lokasi penelitian menunjukkan dan terlihat jelas bahwa dengan adanya alat penyedok sampah yang di sediakan oleh Pemerintah Kabupaten Bantaeng untuk membersihkan saluran air dan maka akan memudahkan menangani dan menanggulangi bencana banjir karena air mengalir sesuai pada tempatnya dan tidak tersumbak lagi yang dapat mengakibatkan banjir dan terpeliharanya lingkungan dengan baik.

c. Penyedian lahan pembangunan;

Penyediaan lahan tempat pembangunan waduk adalah sala tindakan yang di ambil oleh Pemerintah Daerah Kabupaten Bantaeng untuk melaksanakan pembangunan waduk yang sudah menjadi kewajiban dan tanggung jawabnya seorang pemerintah. Berikut adalah pernyataan dari Kepala Dinas BPBD mengatakan:

"Penyedian lahan waduk yang disediakan adalah seluas 10 hektar tapi untuk saat sekarang baru 5 hektar terpakai selebihnya itu dipersiapkan untuk mengantisipasi jika sewaktuwaktu tempat yang di bangun yang srluas 5 hektar tersebut tidak mampu untuk menampung banyaknya debit air. (Wawancara MM)

Dari hasil pernyataan informan mengambarkan kedudukan lahan penyediaan tempat pembangunan waduk/penampungan air dalam penanggulangan bencana banjir sangatlah penting untuk mempermudah terlaksananya rencana pembangunan yang telah dirancang dan ingin dicapai. Sejalan dengan proses pembangunan yang berkelanjutan yang akan dilaksanakan, diperlukan upaya 
pengaturan dan pengarahan terhadap kegiatan-kegiatan yang dilakukan, dengan prioritas utama untuk menciptakan kembali keseimbangan ekologis lingkungan. Sehubungan dengan masalah banjir, langkah yang diambil adalah melalui kegiatan penataan ruang, dengan penekanan pada pengendalian pemanfaatan ruang, serta kegiatan rekayasa teknis yang mendukung proses penanganan dan pengendalian.

Hal ini tertuang dalam UU RI Nomor 24 Tahun 2007 Pasal 80 ayat 3 Tentang Rencana Tata Ruang Wilayah memuat: (1) Rencana struktur ruang wilayah; (2) Rencana ruang wilayah; (3) Penataan kawasan.

\section{3) Melakukan Penghijauan}

Penghijauan merupakan suatu tindakan yang dilakukan oleh Pemerintah Kabupaten Bantaeng untuk mencegah banyaknya debit air serta meresap air, hal ini dilakukan daerah hulu dengan cara menanam pohon. Dari hasil wawncara dengan informan Kepala bidang logistik Badan Penanggulangan Bencana Daerah di Kabupaten Bantaeng dia mengatakan :

$\begin{array}{lr}\text { "Bahwa penghijauan yang } \\ \text { dilakukan } & \text { adalah } \\ \text { penghijauan } & \text { pada } 3 \\ \text { Kecamatan, } & \\ \text { yakni }\end{array}$

Kecamatan Ulu Ere dengan banyak pohon yang ditanam sebanyak 30 ribu pohon, Kecamatan Sinoa 25 ribu pohon, dan Kecamatan Eremerasa sebanyak 40 ribu pohon. Penghijauan dilakukan dengan cara penanaman pohon terhadap daerah hulu atau daerah pengunungan atau perbukitan yang gundul yang dekat dengan Daerah Aliran
Sungai. Penghijauan dalam hal ini bertujuan sebagai peresap air dari daerah hulu ke daerah hilir ketika terjadi hujan deras, selain itu juga untuk menjaga terjadinya tanah longsor yang dapat mengakibatkan banjir". (Wawancara NAM)

Berdasarkan wawancara diatas, mengambarkan bahwa pentingnya menanam pohon sebagai bentuk penghijauan di daerah hulu untuk meresap titik air ketika terjadi hujan deras, sehingga debit air dari daerah hulu tidak berlebihan menuju Daerah Aliran Sungai yang mengakibatkan pengluapan ke daerah hilir menyebabkan terjadi banjir di daerah daratan rendah (hilir). Kurangnya pohon yang berfungsi untuk meresap air dapat berakibat fatal karena banyak debit air mengalir dari daerah hulu ke daerah aliran sungai tanpa terkendali mengakbibatkan banjir. Pernyataan tersebut didukung oleh hasil wawancara dengan informan salah seorang masyarakat mengatakan:

"Hal yang menyebabkan terjadi bencana banjir di Kecamatan Uluh Ere di Desa Pammelangan akibat karena hutan gundul ditambah dengan terjangan hujan yang deras yang menyebabkan tanah menjadi rubuh karena tidak adanya pohon sebagai peresap air sehingga tanah tersebut menjadi longsor dan menangkal jalur Daerah Aliran Sungai Barene' akhirnya air mengalir bukan pada tempatnya melainkan kedaerah hulu atau daratan rendah. (Wawancara DN) 
Dari hasil wawancara dengan informan masyarakat, maka dapat di katakan perlunya ketegasan pemerintah dan pengawasan agar segera mengambil tindakan tentang pemeliharaan lingkungan dan pelarangan melakukan penebangan liar yang menyebabkan hutan menjadi gundul. Kurang tepatnya perencanaan dalam pemeliharaan lingkungan dan penghijauan dapat menimbulkan banyak debit air dari daerah hulu yang mengalir menuju Daerah Aliran Sungai (DAS) yang dapat menimbulkan banjir yang menimbulkan dampak negatif bagi masyarakat seperti yang dikemukakan sebelumnya.

Terkait dengan kawasan rawan bencana banjir, kegiatan pengendalian pemanfaatan ruang dilaksanakan melalui strategi penanggulangan bencana untuk meminimalkan dampak akibat bencana yang mungkin timbul. Kondisi ini tidak bisa dipisahkan dari pola pengendalian pemanfaatan ruang di bagian hulu, Penghijauan di daerah hulu merupakan salah bentuk upaya yang dilakukan oleh Pemerintah Kabupaten Bantaeng menciptakan pendekatan secara terpadu, menyeluruh, berkelanjutan dan berwawasan dalam pengelolaan lingkungan yang sudah menjadi tanggung jawabnya pemerintah daerah. Sesuai otonomi daerah untuk mengatur dan mengurus rumah tangganya sendiri, termasuk dalam hal menanggulangi bencana banjir yang terjadi di daerah. kondisi dan potensi-potensi serta kemampuan daerah itu sendiri yang disebut dalam Undang-undang Nomor 32 Tahun 2004 yaitu, Daerah berhak, berwewenang dan berkewajiban untuk mengatur, mengurus rumah tangganya sendiri termasuk dalam penanggulagan bencana banjir, sesuai dengan Peraturan Perundangundangan yang berlaku.

4) Membangun dinding pesisir pantai

Tanggul dan dinding penahan banjir adalah bangunan penahan yang dibangun di sepanjang bibir pantai digunakan untuk menahan dan menghindari luapan air laut ketika terjadi abrasi, agar tidak meluap ke dataran rendah. Hasil wawancara dengan informan Kepala bidang Kedaruratan Badan Penanggulangan Badan Daearah Kabupaten Bantaeng mengatakan:

"Bahwa pembangunan
dinding di pesisir pantai
dilakukan untuk mencegah
dan menghindari abrasi air
laut. Saat gelombang air
pasang muka air laut
otomatis akan meningkat
tetapi, dengan adanya
bangunan tanggul dan
dinding dapat melindungi
daerah daratan rendah agar
tidak terjadi banjir derasnnya
obak sehingga tidak mengalir
ke daerah daratan rendah
atau bibir pantai. Panjang
dinding tanggul yang di
bangun kurang lebih 5 km".
(Wawancara H)

Berdasarkan wawancara diatas mengambarkan bahwa tanggul dan dinding penahan banjir dapat menghalangi aliran pada sistem drainase yang ada pada daerah dataran banjir kelaut, sehingga diperlukan perencanaan khusus pada daerah tersebut, yaitu pada saluran drainase dari sungai yang ada dibangun pintu-pintu air atau pintu klep dapat mengalirkan air secara gravitasi ke laut agar tidak mengalir ke daratan rendah atau pemukiman 
warga. Pernyataan tersebut didukung dari hasil wawancara dengan salah seorang masyarakat yang tinggal Mattoangin di daerah pesisir pantai Desa Bonto Jai Kecamatan Bissappu mengatakan:

"Bahwa sebelum Pemerintah
Kabupaten Bantaeng
membangun tanggul dinding
di pesisir pantai, daerah
tempat tinggalnya adalah
salah satu daerah rawan
sering kali dilanda banjir
disebabkan naiknya air
pasang laut dan air kiriman
dari muara sungai menuju
laut". (Wawancara HT)

Hasil wawancara diatas, menunjukkan bahwa kedudukan tanggul dinding pesisir pantai merupakan salah satu hal yang sangat penting di kalangan masyarakat pesisir pantai, sebagai pelindung dari air pasang laut. Tanpa adanya tanggul dinding yang dibangun, air pasang laut akan mudah mengenangi daerah daratan rendah, ketika terjadi pasang maka dengan mudah terjadi bencana banjir. Perlunya tindakan pemerintah memberikan perlindungan terhadap masyarakat yang berada di daerah pesisir pantai dengan cara membangun tanggul dinding di daerah pesisir sebagai pemecah dan penahan ketika terjadi air pasang laut, agar air tidak mengalir kedaerah daratan rendah perkampungan masyarakat yang dapat meresahkan masyarakat dan merugikan masyarakat yang berada di pesisir pantai.

5) Membangun Kesadaran Mayarakat.

Penting membangun komitmen dan kerjasama antara pihak pemerintah dan masyarakat untuk menghindarkan Kabupaten Bantaeng dari bencana banjir. Peryataan di dukung hasil wawacara dengan informan Staf Badan Penanggulangan Bencana Daerah (BPBD) Kabupaten Bantaeng :

"Salah satu cara yang
dilakukan
pemerintah/instansi terkait,
agar masyarakat mempunyai
peran dan partisipasi untuk
ikut serta ralam
penanggulangan $\quad$ bencana
banjir Pemerintah Daerah
Kabupaten rantaeng
membentuk rembaga
organisasi kemasyarakatan
(LIMBAN"). (WawancaraS)

Dari pernyataan di atas, peneliti mendeskripsikan bahwa sebuah organisasi masyarakat sebaiknya dibentuk untuk mengambil tindakan dan mengatur peran serta masyarakat dalam penanggulangan banjir. Dengan adanya suatu lembaga kemasyarakatan melibatkan masyarakat untuk ikut berpartisipasi dalam hal mencegah dan penanggulangan banjir dilakukan secara bertahap, dari pencegahan sebelum banjir penanganan saat banjir, dan pemulihan setelah. Tahapan tersebut berada dalam suatu siklus kegiatan penanggulangan banjir yang berkesinambungan, Pencegahan dilakukan secara menyeluruh, berupa kegiatan fisik seperti pembangunan pengendali banjir di wilayah sungai sampai wilayah dataran banjir dan membersikan daerah aliran sungai supaya tidak tersumbak dan lain-lain. Selaras dengan UUD Nomor 24 Tahun 2007 Pasal 87 ayat 3 yang menimbang: "Partisipasi dan peran serta lembaga dan organisassi kemasyarakatan, bertujuan untuk meningkatkan bertujuan dalam rangka membantu penataan daerah rawan bencana kearah lebih baik dan 
rasa kepedulian kedaerah terhadap daerah rawan bencana".

Dari landasan hukum di atas, peneliti menyimpulkan bahwa kerjasama antara seorang pemerintah, Badan Penanggulangan Bencana Daerah dan masyarakat adalah hal yang paling penting. Pemerintah mempunyai peran penting dalam membangun kesadaran masyarakat agar mau ikut berpartisipasi untuk mencegah dan menanggulangi bencana banjir. Terjalinnya kerjasama lembaga yang terkait antara pemerintah, lembaga organisasi kemasyarakatan, maka dengan mudah melakukan sosialisasi dan pelatihan dini secara langsung kepada masyarakat. Pernyataan tersebut didukung dengan hasil wawancara dengan informan Stap Dinas Penanggulangan Bencana Daerah Kabupaten Bantaeng mengatakan :

"Melakukan sosialisasi
kepada masyarakat tentang
bahaya bencana banjir
dengan meberikan
pengarahan dan peringatan
dini pelatihan dalam
penanggulangan banjir, agar
masyarakat mengerti dan
paham dalam hal tentang
bahaya bencana banjir.
(Wawancara I)

Hasil wawancara di atas, menguraikan adanya sosialisasi kepada masyarakat, maka dengan mudah memberikan pengarahan dan peringatan kepada masyarakat, agar masyarakat sadar tentang bahaya bencana banjir dan penting mencegah dan menanggulangi, dengan adanya pengarahan dan peringatan dini mereka juga memahami apa-apa yang langkah-langkah yang harus ditempuh dan dilakukan dalam mencegah dan menanggulangi bencana banjir tersebut. Dengan begitu pikiran anggota masyarakat akan terbuka dengan sendirinya akan ikut berpartisipasi dalm menjaga, memelihara dan meningkatkan kualitas ruang lebih ditekankan pada keikutsertaan masyarakat untuk lebih mematuhi dan mentaati segala ketentuan normatif yang ditetapkan dalam rencana tata ruang, dan mendorong terwujudnya kualitas ruang yang lebih baik dalam mencengah dan menanggulangi banjir.

Hal tersebut dapat membantu menyoroti apa yang spesial atau bebeda mengenai masyarakat itu, dan dimana perbedaan dari angka nasional. Kelompok masyarakat juga akan berada dalam suatu posisi yang baik untuk saling memperingati dan memberikan informasi antara masyarakat yang satau dengan masyarakat-masyarakat yang lain akan bahaya bencana banjir. Selain itu, memberikan informasi baik secara langsung ataupun melalui media komunikasi seperti, tv, radio atau via seluler kepada masyarakat, merupakan hal penting karena dengan memberikan pengarahan dapat memberikan informasi yang relevan tentang hal-hal yang harus dilakukan dalam mencegah dan menanggulangi bencana tersebut. Pernyataan tersebut didukung dari wawancara dengan informan Staf (BPBD) mengatakan:

"Pentingnya untuk
memberikan informasi
kepada kelompok masyarakat
tentang bahaya bencana
banjir mereka paham apa
yang dilakukan dalam
melakukan tindakan dan
mereka tidak membuat suatu
tindakan yang merusak
misalnya, penebangan hutan,
membuang sampah bukan
pada tempatnya sehingga


dapat menyebabkan banjir". (Wawancara T)

Hasil wawancara dari informan terkait diatas, peneliti mendeskripsikan bahwa dengan memberikan informasi yang relevan pada penduduk kelompok masyarakat bisa melakukan suatu peran yang bermanfaat. Informasi ini merupakan hal yang sangat penting bagi masyarakat dalam merencanakan berbagai cara yang paling baik untuk memenuhi kebutuhannya, dan bagaimana melibatkan penduduk sebanyak mungkin dalam berbagai proses pengembangan masyarakat dalam menanggulangi banjir.

\section{Pelaksanaan Kebijakan Pemerintah Daerah dalam Penanggulangan Banjir di Kabupaten Bantaeng}

Pelaksanaan penanggulangan bencana banjir dilaksanakan secara terpadu atau terkordinir dengan melibatkan seluruh potensi pemerintah dan lapisan masyarakat. Upaya preventif harus diutamakan bagaimana penanggulan banjir tewujud dan korban jiwa dapat ditanggulangi atau diperhitungkan dalam menanganinya. Berikut hasil wawancara dengan informan Kepala Dinas Badan Penanggulangan Bencana Daerah (BPBD) mengakatan:

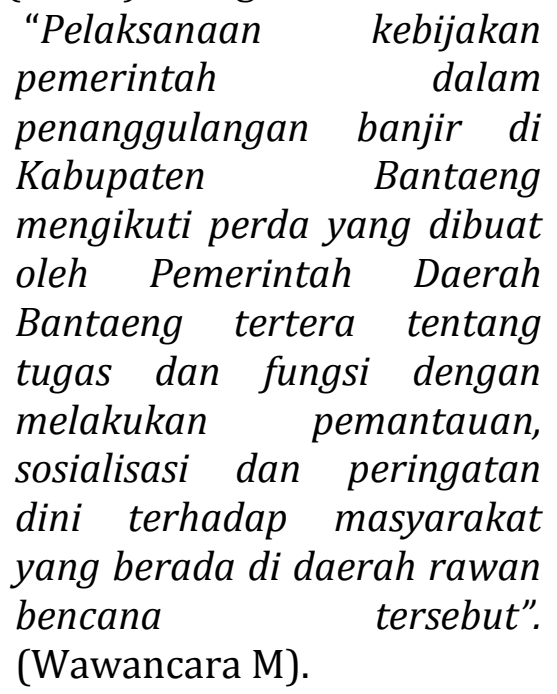

Dari hasil wawancara di atas dan hasil identifikasi data di lapangan dilakukan peneliti menyatakan pelaksanaan tahap rehabilitas adalah pemerintah daerah terhadap penanggulangan bencana banjir di Kabupaten Bantaeng melalui penggalangan kekuatan dengan melalui semua pihak, melalui pemberdayaan masyarakat serta kampanye bahaya bencana banjir bagi kehidupan manusia dan perlunya melakukan penanggulangan bencana banjir. Pemetaan langkah pertama dalam mengambil strategi mitigasi adalah melakukan peninjauan daerah rawan bencana banjir. Agar selalu memberikan antisipasi untuk melakukan penaggulangan agar bencana banjir tidak terjadi dan Pemantauan terhadap kawasan rawan bencana banjir dengan mengetahui tingkat kerawanan secara dini, maka dapat mengambil tindakan dalam penanggulangan tehadap bencana banjir. Berikut adalah hasil wawan cara sekretaris (BPBD) Kabupaten Bantaeng mengatakan :

"Pemantauan yang dilakukan dengan cara meninjau kawasan rawan bencana banjir dan terjun langsung ke lapangan /kawasan rawan bencana dan melihat apa-apa saja yang perlu dibenahi dengan begitu akan lebih mudah melaksanakan penataan ruang yang perlu ditata". (Wawancara $\mathrm{H}$ ).

Dari hasil wawancara di atas menujukkan pemantauan penyelenggaran penanggulangan bencana banjir diperlukan sebagai proses pelaksanaan kebijakan dari Pemerintah Daerah Kabupaten Bantaeng dalam penanggulangan bencana banjir. hal tersebut di dukung dengan adanya UU RI Nomor 24 
Tahun 2007 Pasal 42 tentang Tanggung jawab dan wewenang menimbah bahwa: (1) Pelaksanaan dan penegakan rencana tata ruang sebagaimana yang di maksud dalam pasal 35 huruf $\mathrm{f}$ dilakukan untuk mengurangi resiko bencana yang mencakup pemberlakuan peraturan tentang penataan ruang, satandar, dan keselamatan; (2) Pemerintah secara berskala melaksanakan pemantauan dan evaluasi terhadap penataan tata ruang dan pemenuhan standar keselamatan.

\section{E. PENUTUP}

Strategi penanggulangan bencana banjir di Kabupaten Bantaeng yang telah dilakukan yaitu dengan menyediakan sarana dan prasarana berupa alat dan lahan untuk membangun waduk, sebagai penampung air dari Daerah Aliran Sungai (DAS) dan anak sungai ketika datang terjangan hujan dan kesadaran masyarakat dalam pengelolaan salauran air secara profesional sehingga air dapat mengalir ke tempat yang disediakan, meski didukung oleh penghijauan yang dilakukan di daerah hulu sebagai peresap titik air ketika turun hujan, agar air yang berasal dari daerah hulu tidak terlalu banyak mengalir ketempat penampungan yang dapat menyebabkan pengeluapan ke daerah hilir/daerah daratan rendah, sehingga tidak terjadi banjir dan pembangunan tanggul dinding di peisir pantai sebagai pemecah ombak dan menahan menahan abrasi air laut ketika terjadi pasang air laut, agar tidak mengalir ke daratan rendah.

Penanggulangan bancana banjir berdampak positif terhadap lingkungan hidup yaitu terciptanya kondisi lingkungan hidup yang aman, tertib, bersih, indah dan sejuk dan masyarakat pun tidak merasa khawatir dan tidak di hantui rasa takut. Pelaksanaan kebijakan pemerintah daerah dalam penanggulangan bencana banjir di laksanakan secara terpadu atau koordinir. Penggalangan kekuatan dengan melalui semua pihak, melalui pemberdayaan masyarakat serta kampanye penghijauan untuk melakukan penanggulangan bencana banjir melibatkan seluruh potensi pemerintah dan lapisan masyarakat.

Kepada Pemerintah Daerah Kabupaten Bantaeng dan instansi yang berwenang terhadap pelaksanaan penanggulangan bencana banjir, membentuk suatu badan khusus menangani banjir. Kepada masyarakat yang belum terlibat dalam kegiatan penanggulangan bencana banjir agar dapat terlibat di dalamnya agar penanggulangan dapat maksimal.

\section{DAFTAR PUSTAKA}

Direktorat Jenderal Bina Pengelolaan Daerah Air Sungai (Ditjen BPDAS). 2008. Tentang pengelolaan Daerah Aliran Sungai (DAS). Cipta, Bantaeng.

Umar, Husein. 2001.Strategic Action. Jakarta: Gramedia Pustaka Utama.

Badan Nasional Penanggulangan Bencana. 2010. Data Bencana yang terjadi di Indonesia, Jakarta Pusat.

Badan Nasional Penanggulangan Bencana, 2012. Jurnal penanggulangan bencana, Jakarta Pusat.

Flores, Eco, 2014.Pengurangan resiko Bencana, Source Wikimedia Green Indonesia.

Himpunan Peraturan Perundang-undangan. 2008. Penanggulangan Bencana. Bandung. Fokus media.

Syaripin, Pipin. 2004. Pemerintah Daerah di Indonesia dilengkapi dengan Undang- 
undang No. 32 Tahun 2004. Bandung, pustaka setia.

Abdullah, Nurdin. 2009. Alokasi Anggaran dalam Pembanggunan Bantaeng bebas Banjï, Gramedia Pustaka.

Ife, Jim dan Tesoriero, 2008. Community Development: Alternatif Pengembangan Masyrakat di Era Globalisasi. Yogyakarta, Pustaka Pelajar.
Dokumen :

Peraturan Daerah Kabupaten bantaeng No 2, 2013. Tentang Pembentukan Penanggulangan Daerah Kabupaten Bantaeng. Dinas Badan Penanggulangan Bantaeng(BPBD). 